\title{
Biochemical changes in cultivars of sweet oranges infected with citrus tristeza virus
}

\author{
N. Munir ${ }^{a}$ (D), A. A. Hameed ${ }^{a}$ (D), R. Haq ${ }^{a *}$ (D) and S. Naz ${ }^{a}$

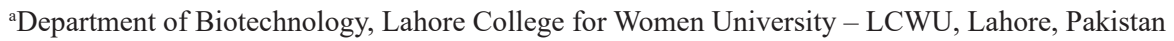 \\ *e-mail: rukhama87@gmail.com
}

Received: April 3, 2018 - Accepted: November 29, 2018 - Distributed: November 30, 2019

(With 7 figures)

\begin{abstract}
Citrus fruit production occupies a place of considerable importance in the economy of the world including Pakistan. Tristeza disease caused by Citrus Tristeza Virus (CTV) exists in various forms that may or may not cause symptoms in the plants. The bioactive compounds and antioxidants are naturally present in plants and provide a defense mechanism that is generally accelerated in response to a stress. The objective of the present study was to target and analyze the citrus plants that were CTV positive to observe the changes in the enzymatic and non-enzymatic antioxidants of citrus (Sweet Oranges only). It was observed that in response to CTV infection, both the non-enzymatic antioxidants (total flavonoid, ascorbic acid, phenolic acid) and enzymatic antioxidants (catalase, superoxide dismutase and peroxidase) activities showed an increasing trend overall. The profiling of antioxidants in response to a viral infection may help in the discovery of new biomarkers that can be used as a monitoring tool in disease management.
\end{abstract}

Keywords: antioxidant, citrus, CTV, enzymes, sweet oranges.

\section{Mudanças bioquímicas em vários cultivares de laranjas doces infectadas com o vírus citrus tristeza}

\begin{abstract}
Resumo
As frutas cítricas ocupam um lugar de considerável importância na economia do Paquistão, assim como o resto do mundo. A doença da tristeza causada pelo Vírus da Tristeza dos Citros (CTV) existe em várias formas que podem ou não apresentar sintomas nas plantas. Os compostos bioativos e antioxidantes estão naturalmente presentes nas plantas e fornecem um mecanismo de defesa que é geralmente acelerado em resposta a um estresse. O objetivo do presente estudo foi analisar as alterações causadas pelo CTV nos antioxidantes enzimáticos e não enzimáticos de laranjas doces. Foi observado que, em resposta ao ataque de CTV, os antioxidantes não enzimáticos como flavonoides totais, ácido ascórbico, ácido fenólico e antioxidantes enzimáticos, como as atividades de catalase, superóxido dismutase e peroxidase, geralmente mostram uma tendência crescente. O perfil de antioxidantes em resposta a um ataque viral pode ajudar na descoberta de novos biomarcadores que podem ser usados como uma ferramenta de monitoramento no gerenciamento de doenças.
\end{abstract}

Palavras-chave: antioxidante, citrus, CTV, enzimas, sweet oranges.

\section{Introduction}

Citrus is a popular fruit in many parts of the world due to its unique taste, flavor and numerous health assistances associated with them. Biological antioxidants are the main complexes that provide defense to the biological systems to combat the destructive effects of events that cause excessive oxidation. Plants require antioxidant compounds not only for pigmentation, reproduction, growth but also for the resistance to pathogens (Gorinstein et al., 2004).

Unlike animals, plants cannot rely on physical movement to escape from predators hence they synthesize a greater range of secondary compounds and therefore they adopt a chemical resistance mechanism against various pathogens and predators (Lattanzio et al., 2006). Citrus plants have both enzymatic and non-enzymatic antioxidant compounds that act as a scavenger to tolerate the damaging effect of stress conditions subjected to plants. Amongst the non-enzymatic scavengers are included many phenolic compounds, ascorbic acid, and vitamin E. Enzymatic scavenging activity is due to compounds like hydrogen peroxide, hydroxyl free radical and singlet oxygen (Lin et al., 2014). These antioxidants generally show incredible activity in response to pathogen attack thus play a significant role in defense mechanisms of plant (Das et al., 2010). 
Citrus Tristeza virus (CTV) is a member of the genus Closterovirus and triggers one of the deadliest pathogenic diseases found in citrus fruit (Djelouah and D'Onghia, 2000). CTV causes significant damage to the citrus crop including poor fruit quality, yield and stem pits of the citrus plants (Cambra et al., 2000; Zhou et al., 2011). Aphids are responsible for the spread of CTV and is responsible for the cause of many epidemics. Major symptoms of Tristeza disease are yellow seedlings (CTV-SY); quick decline (CTV-D), stem pitting (CTV-SP). Many of these strains may exist in citrus or they may come together as complex making citrus plant decay quickly (Atta et al., 2012). When encountered with reactive oxygen species (ROS), the citrus plants show defense for themselves by the activation of many antioxidant enzymes like superoxide dismutase (SOD), glutathione peroxidase (GRX), catalase (CAT), and glutathione reductase (GR) which inhibit the activity of reactive oxygen species (Elkahoui et al., 2005).

Keeping in view the importance of the antioxidants and their role in defense mechanism of the plants, the present study was focused to check CTV positive citrus plants along with the positive and negative controls for the changes caused by the virus in the enzymatic and non-enzymatic antioxidants of Citrus sinensis (Sweet Oranges).

\section{Materials and Methods}

\subsection{Sample collection}

The fully developed upper leaves (8-10) and fruit samples (3) of $11 \mathrm{CTV}$ positive commercial cultivars (Campbell, Casa Grande, Frost Rose, Hamlin, Hinckley, Jaffa Koozan Mars early, New hall, Sanguinello, Tarocco) of sweet oranges including healthy control were collected from the Citrus Research Institute of Sargodha (CRI). The ripeness of citrus fruits and leaves was determined on the basis of skin, color, and physical signs. The samples were kept in $-80^{\circ} \mathrm{C}$ prior to use.

\subsection{CTV confirmation}

Prior to collection, a study was done on the same samples with a total of 100 sweet orange plants, that were checked for the presence or absence of CTV. The presence or absence of CTV was confirmed via RT-PCR. Furthermore, the screened CTV positive plants were recollected and extracted for the enzymatic and non-enzymatic assay.

\subsection{Extraction procedure}

Two grams of citrus leaves were crushed in $0.1 \mathrm{M}$ phosphate buffer and $0.1 \%$ polyvinylpyrlidine (PVP) with the help of pestle and mortar. The slurry was centrifuged at 14,000 rpm for 10 minutes and then supernatant was used for quantitative estimation of antioxidants present in samples. Citrus fruits were peeled and squeezed to get the juice. The extraction procedure adopted for fruit juice was as described by Franke et al. (2004).

\subsection{Qualitative analysis of healthy and infected cultivars}

The determination of the juice percent content test is the primary step for the recognition of fruit quality. The juice content was calculated using the following formula \%
Juice $=$ Juice weight net $\mathrm{x}$ 100/Fruit weight. Total soluble solids (Brix) are an important step in the recognition of fruit quality. The minerals present in juice and citric acid contributed to the soluble solids. The soluble solid content was determined by a refractometer method as described by Suntornsuk et al. (2002).

Citric acid, that is the core constituent of citrus fruit juice was determined by titration method using phenolphthalein as an indicator. The acid content was determined as follows: Amount of $0.1 \mathrm{M}$ Sodium Hydroxide added="X"ml; Mililiters of $0.1 \mathrm{M}$ sodium Hydroxide $\mathrm{x} 0.064=$ citric acid concentration (g/100ml); "X" x0.064 ="Y"g/100mL citric acid.

The sugar-acid ratio was determined to measure the distinctive taste of citrus by applying the given formula: Sugar concentration ="X" Brix; Citric Acid Concentration= "Y" g per 100ml; Citric acid concentration ="Z'.

\subsection{Non-enzymatic antioxidant assays}

The total flavonoids content of the citrus varieties was calculated by colorimetric method. The total phenolic components were examined with Folin-Ciocalteu reagent method with slight modifications. The complex phosphomolybdenum method was used for the quantitative analysis of total ascorbic acid contents from eleven different citrus cultivars that were commonly used to show the ascorbic acid content as well as antioxidant activity. Total antioxidant activity of citrus cultivars was calculated using DPPH method (Ghafoor et al., 2010). The activities were determined by the enzyme/substrate UV-Vis spectrophotometric analysis.

\subsection{Enzymatic antioxidant assays}

Methods of Doria et al. (2015) was used to estimate the Protein content, Catalase (CAT) activity, Superoxide Dismutase (SOD) activity, and Guaiacol Peroxidase (GPX) activity. For the determination of peroxidase and catalase activities, and for the calculation of total protein concentration, $200 \mathrm{mg}$ of leaf tissue were homogenized with a mortar and pestle in liquid nitrogen and $1.5 \mathrm{~mL}$ of $0.1 \mathrm{M}$ potassium phosphate buffer, $\mathrm{pH} 7.0$, centrifuged at $12000 \mathrm{~g}$ for $30 \mathrm{~min}$ at $4{ }^{\circ} \mathrm{C}$ and the supernatant separated for enzyme assays. Concentration of the total soluble protein of the enzyme extract was determined using bovine serum albumin as a standard. For the measurement of catalase activity (CAT), $0.2 \mathrm{~mL}$ of plant extract was incubated for $1 \mathrm{~min}$ at $37^{\circ} \mathrm{C}$ in $1 \mathrm{~mL}$ of reaction mixture consisting of $65 \mathrm{mM}$ hydrogen peroxide and $60 \mathrm{mM}$ potassium phosphate buffer, $\mathrm{pH}$ 7.4. The reaction was stopped by adding $1 \mathrm{~mL}$ of $32.4 \mathrm{mM}$ ammonium molybdate and the formation of the yellow-colored molybdate-peroxide complex was observed by spectrophotometry every $20 \mathrm{~s}$ for $5 \mathrm{~min}$ at $405 \mathrm{~nm}$. For measurement of Guaiacol Peroxidase (GPX), $10 \mathrm{lL}$ of plant extract were added to the reaction mixture (giving a final volume of $3 \mathrm{~mL}$ ) containing $50 \mathrm{mM}$ phosphate buffer, $20 \mathrm{mM}$ guiacol (Sigma-Aldrich) and 40 mM H2O2 (pH 7.0; Macron). Total GPX activity was determined by monitoring the formation of tetraguiaicol from guiacol in the presence of $\mathrm{H} 2 \mathrm{O} 2$, observed by spectrophotometry at $470 \mathrm{~nm}$. The increase in absorbance 
was recorded every $20 \mathrm{~s}$ for $5 \mathrm{~min}$. For determination of superoxide dismutase (SOD) activity, $200 \mathrm{mg}$ of plant tissue were homogenized in liquid nitrogen and $1.5 \mathrm{~mL}$ of $50 \mathrm{mM}$ potassium phosphate buffer, $1 \mathrm{mM}$ EDTA and $1 \%$ polyvinyl pyrrolidone (PVP; $\mathrm{pH}$ 7.0). The homogenate was centrifuged at $15000 \mathrm{~g}$ for $30 \mathrm{~min}$ and the supernatant was retained for the enzyme assay. The enzyme activity was measured using the inhibition of the nitrobluetetrazolium chloride reduction. The reaction mixture contained $50 \mathrm{mM}$ potassium phosphate buffer, $\mathrm{pH}$ 7.8, $0.1 \mathrm{mM}$ EDTA (Carlo Erba), 13 mM L-methionine (AppliChem), 75 lM NBT, 2 1M riboflavin (Acros Organics) and 0-100 $\mathrm{lL}$ of enzyme extract in a final volume of $3 \mathrm{~mL}$. The reaction was initiated when the tubes were illuminated with $15 \mathrm{~W}$ fluorescent lamps for $10 \mathrm{~min}$ and stopped by switching off the lamps. The non-illuminated reaction mixture with enzyme as a blank. One unit of SOD activity was defined as the amount of enzyme that caused $50 \%$ inhibition of NBT reduction.

\subsection{Statistical analysis}

The data were analyzed through IBM SPSS version 20 pro using one-way ANOVA. The significance of treatment means at a level of $\mathrm{P} \leq 0.05$.

\section{Results and Discussion}

\subsection{Qualitative assay}

It is evident from Table 1 that a significant $(\mathrm{P}=0.049)$ reduction in fruit weight and size was recorded as a response to CTV infection when compared with the healthy samples. Simultaneously, the CTV infection of the samples resulted in a decrease in $\mathrm{pH}$ as compared to the healthy fruits data showed in Table 2. Highest decrease in $\mathrm{pH}$ after infection was recorded in fruit juice of Frost Rose cultivar, where $\mathrm{pH}$ was decreased from 4.26 to $3.96(\mathrm{P}=0.0459)$. However, in leaves and peels of healthy and infected fruits generally a decrease in $\mathrm{pH}$ after CTV infection was observed. The highest decrease in $\mathrm{pH}$ of leaves was recorded in Hinckley where $\mathrm{pH}$ level decreased from 4.8 to 3 and maximum change in
$\mathrm{pH}$ of peel $(\mathrm{P}=0.048)$ was observed in the case of Hamlin cultivar where $\mathrm{pH}$ decreased from 4.0 to $2.5(\mathrm{P}=0.049)$. Table 3 indicated the effect of CTV infection on soluble solids, citric acid, and sugar-acid ratio. The total soluble solid ratio was decreased in the infected plants in comparison to the healthy plants and was also recorded in fruit juice of Casa Grande cultivar where it decreased from 12.1 Brix to 9.29 Brix ( $\mathrm{P}=0.04)$. Citric acid content also showed a decline in infected cultivars. In fruit juice of Mars Early cultivar citric acid content was $1.9 \mathrm{~g} / \mathrm{ml}$ while in infected fruits it was $1.2 \mathrm{~g} / \mathrm{ml}(\mathrm{P}=0.041)$. The decrease in sugar: acid ratio in infected samples was recorded in fruit juice of New Hall ranged from 7.9:1 to 10.1:1 and Casa Grande cultivar from 12.6:1 to $10.4: 1$.

\subsection{Non-enzymatic antioxidant profiling}

It is evident from the Figure 1 that CTV infection of citrus cultivars resulted in an increase in flavonoid content as compared to the healthy fruits $(\mathrm{P}=0.01)$. The highest increase was observed in flavonoid content in fruit juice of CTV infected plants of Campbell cultivar. In healthy plants the flavonoid content was $0.17 \mathrm{mg} / \mathrm{g} \mathrm{FW}$ while in fruit juice of plants infected with CTV the value was $3.69 \mathrm{mg} / \mathrm{g} \mathrm{FW}$ However, in leaves and peels of healthy and infected fruits generally increase flavonoid content was observed after CTV infection. The highest increase of flavonoid content in leaves was recorded in the New Hall and the maximum change in flavonoid content of peel was observed in the case of Hamlin cultivar.

It is evident from the Figure 2 that CTV infection of citrus cultivars resulted in an increase in Phenolic content as compared to the healthy fruits. The increase in phenolic content was observed in fruit juice of New Hall cultivar positive for CTV with a value of $31 \mathrm{mg} / \mathrm{ml}$ to $82 \mathrm{mg} / \mathrm{ml}$. However, in leaves and peels of healthy and infected fruits, generally increased phenolic content was observed after CTV infection. The highest increase in leaves was recorded in Taracco cultivar and maximum change in the phenolic content of peel was observed in the case of Mars Early cultivar.

Table 1. Effect of CTV infection on fruit weight and Fruit size of different citrus cultivars.

\begin{tabular}{|c|c|c|c|c|c|}
\hline \multirow{2}{*}{$\begin{array}{l}\text { Sr. } \\
\text { No. }\end{array}$} & \multirow[t]{2}{*}{ Citrus cultivars } & \multicolumn{2}{|c|}{$\begin{array}{c}\text { Fruit weight } \\
(\mathrm{g} \pm \text { S.E })\end{array}$} & \multicolumn{2}{|c|}{$\begin{array}{c}\text { Fruit size } \\
(\mathrm{cm} \pm \text { S.E })\end{array}$} \\
\hline & & Healthy fruit & Infected fruit & Healthy & Infected \\
\hline 1. & Campbell & $255 \pm 0.5$ & $239 \pm 0.1$ & $46.2 \pm 1.0$ & $45.1 \pm 0.1$ \\
\hline 2. & Casa Grande & $205 \pm 0.1$ & $197 \pm 0.1$ & $44 \pm 1.5$ & $42 \pm 0.1$ \\
\hline 3. & Frost Rose & $168 \pm 0.1$ & $174 \pm 0.5$ & $36 \pm 0.2$ & $34 \pm 0.5$ \\
\hline 4. & Hamlin & $176 \pm 0.2$ & $169 \pm 0.5$ & $36 \pm 0.5$ & $35 \pm 0.2$ \\
\hline 5. & Hinckley & $145 \pm 0.1$ & $134 \pm 0.5$ & $30 \pm 0.5$ & $29 \pm 0.5$ \\
\hline 6. & Jaffa & $170 \pm 0.5$ & $162 \pm 0.1$ & $50 \pm 0.1$ & $47 \pm 0.1$ \\
\hline 7. & Koozan & $169 \pm 1.0$ & $155 \pm 0.1$ & $36 \pm 1.0$ & $34.7 \pm 0.1$ \\
\hline 8. & Mars early & $230 \pm 0.1$ & $210 \pm 1.0$ & $43 \pm 1.0$ & $41 \pm 1.0$ \\
\hline 9. & New hall & $240 \pm 0.5$ & $200 \pm 1.0$ & $44 \pm 0.5$ & $42.3 \pm 1.0$ \\
\hline 10. & Sanguinello & $165 \pm 0.5$ & $150 \pm 1.5$ & $34 \pm 1.0$ & $31 \pm 0.5$ \\
\hline 11. & Tarocco & $182 \pm 1.0$ & $179 \pm 0.05$ & $52 \pm 0.1$ & $\mathbf{5 0} \pm \mathbf{0 . 0 5}$ \\
\hline
\end{tabular}


Table 2. Effect of CTV infection on $\mathrm{pH}$ of citrus fruits, leaves, and peels.

\begin{tabular}{|c|c|c|c|c|c|c|c|}
\hline \multirow[b]{2}{*}{$\begin{array}{l}\text { Sr. } \\
\text { No. }\end{array}$} & \multirow[b]{2}{*}{ Citrus cultivars } & \multicolumn{6}{|c|}{$\begin{array}{c}\text { pH of samples } \\
\text { Mean } \pm \text { S.E }\end{array}$} \\
\hline & & $\begin{array}{c}\text { Healthy } \\
\text { Fruits }\end{array}$ & $\begin{array}{l}\text { Infected } \\
\text { fruits }\end{array}$ & $\begin{array}{c}\text { Healthy } \\
\text { leaves }\end{array}$ & $\begin{array}{c}\text { Infected } \\
\text { leaves }\end{array}$ & $\begin{array}{l}\text { Healthy } \\
\text { fruit peel }\end{array}$ & $\begin{array}{l}\text { Infected } \\
\text { fruit peels }\end{array}$ \\
\hline 1. & Campbell & $4.59 \pm 1.0$ & $4.3 \pm 1.6$ & $6.2 \pm 1.0$ & $5.3 \pm 1.0$ & $5.5 \pm 0.1$ & $5.1 \pm 1.0$ \\
\hline 2. & Casa Grande & $4.86 \pm 1.0$ & $4.78 \pm 0.7$ & $5.6 \pm 1.0$ & $4.0 \pm 1.0$ & $5.0 \pm 0.1$ & $4.5 \pm 1.0$ \\
\hline 3. & Frost Rose & $4.26 \pm 1.0$ & $3.96 \pm 1.4$ & $4.1 \pm 0.1$ & $3.6 \pm 1.0$ & $3.5 \pm 0.1$ & $3.0 \pm 0.1$ \\
\hline 4. & Hamlin & $4.44 \pm 0.1$ & $4.36 \pm 0.8$ & $5.8 \pm 0.1$ & $6.7 \pm 0.1$ & $4.0 \pm 0.5$ & $2.5 \pm 0.6$ \\
\hline 5. & Hinckley & $4.49 \pm 1.1$ & $4.46 \pm 0.9$ & $4.8 \pm 0.1$ & $3.0 \pm 0.1$ & $5.1 \pm 0.8$ & $4.9 \pm 0.7$ \\
\hline 6. & Jaffa & $4.36 \pm 0.05$ & $4.30 \pm 1.0$ & $5.9 \pm 0.1$ & $5.3 \pm 0.1$ & $4.8 \pm 0.9$ & $4.0 \pm 0.5$ \\
\hline 7. & Koozan & $4.48 \pm 0.1$ & $4.40 \pm 0.9$ & $4.7 \pm 0.9$ & $3.9 \pm 0.9$ & $5.0 \pm 1.0$ & $3.8 \pm 0.1$ \\
\hline 8. & Mars early & $3.92 \pm 1.0$ & $3.94 \pm 1.2$ & $5.7 \pm 1.0$ & $4.5 \pm 0.5$ & $4.4 \pm 1.0$ & $4.3 \pm 0.1$ \\
\hline 9. & New hall & $4.62 \pm 1.0$ & $4.52 \pm 0.1$ & $6.0 \pm 1.0$ & $5.2 \pm 0.8$ & $6.0 \pm 0.5$ & $5.4 \pm 1.0$ \\
\hline 10. & Sanguinello & $4.4 \pm 1.0$ & $4.38 \pm 1.0$ & $6.5 \pm 0.5$ & $6.6 \pm 0.1$ & $5.9 \pm 0.7$ & $5.0 \pm 1.0$ \\
\hline 11. & Tarocco & $4.98 \pm 0.01$ & $4.81 \pm 1.0$ & $5.6 \pm 0.8$ & $5.1 \pm 1.1$ & $4.9 \pm 0.1$ & $4.2 \pm 1.0$ \\
\hline
\end{tabular}

Table 3. Comparison of total soluble solids, citric acid content, and sugar: acid ratio of healthy and CTV infected citrus fruits.

\begin{tabular}{|c|c|c|c|c|c|c|c|}
\hline \multirow[t]{2}{*}{$\begin{array}{l}\text { Sr. } \\
\text { No }\end{array}$} & \multirow[t]{2}{*}{ Citrus cultivars } & \multicolumn{2}{|c|}{$\begin{array}{c}\text { Total soluble solids } \\
\text { (Brix) } \\
\text { Mean } \pm \text { S.E }\end{array}$} & \multicolumn{2}{|c|}{$\begin{array}{c}\text { Citric acid content } \mathrm{g} / \mathrm{ml} \\
\operatorname{Mean} \pm \mathrm{S.E}\end{array}$} & \multicolumn{2}{|c|}{ Sugar acid ratio:1 } \\
\hline & & Healthy & Infected & Healthy & infected & Healthy & Infected \\
\hline 1. & Campbell & $11.0 \pm 0.1$ & $9.69 \pm 0.1$ & $1.04 \pm 0.1$ & $1.0 \pm 0.1$ & 10.6: 1 & 9.69: 1 \\
\hline 2. & Casa Grande & $12.1 \pm 0.1$ & $9.29 \pm 0.1$ & $0.96 \pm 0.5$ & $0.89 \pm 0.1$ & 12.6:1 & 10.4:1 \\
\hline 3. & Frost Rose & $10.2 \pm 0.4$ & $9.18 \pm 1.0$ & $1.07 \pm 1.1$ & $1.0 \pm 0.5$ & 9.8:1 & 9.5: 1 \\
\hline 4. & Hamlin & $11.9 \pm 0.9$ & $10.9 \pm 1.0$ & $1.08 \pm 0.5$ & $0.99 \pm 1.0$ & 11: 1 & 10: 1 \\
\hline 5. & Hinckley & $7.8 \pm 1.0$ & $6.5 \pm 0.8$ & $1.05 \pm 1.0$ & $0.98 \pm 1.0$ & 7.4: 1 & 6.6: 1 \\
\hline 6. & Jaffa & $16 \pm 1.0$ & $14 \pm 0.9$ & $1.5 \pm 1.0$ & $1.1 \pm 1.5$ & 10.6: 1 & 12.7: 1 \\
\hline 7. & Koozan & $9.9 \pm 1.0$ & $9.1 \pm 1.0$ & $1.2 \pm 1.0$ & $1.0 \pm 0.5$ & 8.25: 1 & 9.1: 1 \\
\hline 8. & Mars early & $8.5 \pm 0.05$ & $7.1 \pm 1.2$ & $1.9 \pm 0.1$ & $1.2 \pm 1.0$ & 4.47: 1 & 5.9: 1 \\
\hline 9. & New hall & $18.1 \pm 0.05$ & $15.6 \pm 1.3$ & $1.3 \pm 0.1$ & $1.1 \pm 0.1$ & 13.9: 1 & 14.1:1 \\
\hline 10. & Sanguinello & $11.1 \pm 0.1$ & $10.1 \pm 1.1$ & $1.4 \pm 0.5$ & $1.0 \pm 0.1$ & 7.9: 1 & 10.1: 1 \\
\hline 11. & Tarocco & $7.7 \pm 1.0$ & $6.5 \pm 0.1$ & $1.3 \pm 0.3$ & $1.2 \pm 0.9$ & 5.9: 1 & 5.4: 1 \\
\hline
\end{tabular}

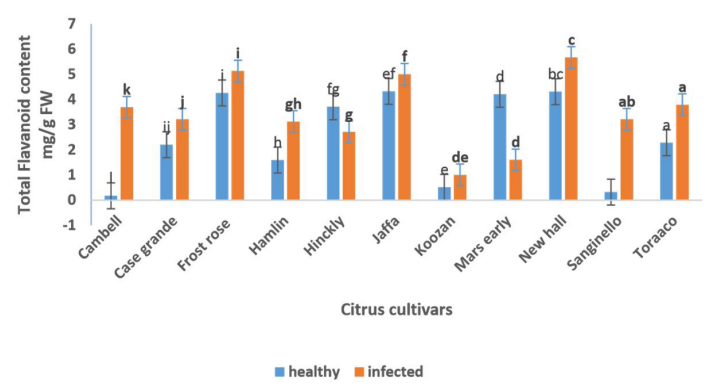

Figure 1. Effect of Citrus Tristeza virus infection on Total flavonoid content of different citrus fruits.

It is evident from the Figure 3 that CTV infection of citrus cultivars resulted in an increase in ascorbic acid content as compared to the healthy fruits. Highest increase in ascorbic acid content after infection was recorded in fruit juice of New Hall cultivar where flavonoid content changed from $4.9 \mathrm{mg} / \mathrm{ml}$ to $7.6 \mathrm{mg} / \mathrm{ml}$. However, in leaves and peels of healthy and infected fruits, generally an increased phenolic content was observed after CTV infection. The highest increase in leaves was recorded in Taracco and maximum change in the phenolic content of peel was observed in the case of Sanginello cultivar.

Similarly, the Figure 4 showed that CTV infection of citrus cultivars resulted in an increase in antioxidant content as compared to the healthy fruits. The highest increase in antioxidant content after infection was recorded in fruit juice of Campbell cultivar where antioxidant content increased from $4.9 \%$ to $7.6 \%$. However, in leaves and peels of healthy and infected fruits, generally an increased phenolic content was observed after CTV infection. The highest increase in leaves was recorded in Mars Early and maximum change in the antioxidant content of peel was observed in the case of Case Grande cultivar. 


\subsection{Enzymatic antioxidant profiling}

The activity of CAT (Figure 5) was observed and compared in the infected and healthy samples. The highest increase was observed in catalase activity after infection was recorded in fruit juice of Mars Early cultivar where catalase activity was $49.9 \mathrm{u} / \mathrm{ml} / \mathrm{min}$ to $58.9 \mathrm{u} / \mathrm{ml} / \mathrm{min}$ in healthy and infected plants respectively. However, in leaves and peels of healthy and infected fruits generally an increase catalase activity was observed in CTV infected plants. The highest increase in leaves was recorded in Frost Rose and maximum change in catalase activity of peel was observed in the case of Mars Early cultivar.

The activity of SOD (Figure 6) resulted in a significant increase in superoxide dismutase activity as compared to the healthy fruits $(\mathrm{P}=0.048)$. The highest increase in superoxide dismutase activity after infection was recorded in fruit juice of New Hall cultivar where superoxide dismutase activity increased from $49.9 \mathrm{u} / \mathrm{ml} / \mathrm{min}$ to $58.9 \mathrm{u} / \mathrm{ml} / \mathrm{min}$. However, in leaves and peels of healthy and infected fruits generally an increased superoxide dismutase activity was observed after CTV infection. The highest change in superoxide dismutase activity of peel was observed in the case of Hinckley cultivar.

It was evident from the Figure 7 that CTV infection of citrus cultivars resulted in an increase in peroxidase activity as compared to the healthy fruits. The highest increase in peroxidase activity after infection was recorded in fruit juice of Hinckley cultivar where peroxidase activity increased from 49.9 to 58.9. However, in leaves and peels of healthy and infected fruits generally an increased peroxidase activity was observed after CTV infection. The highest increase in leaves was recorded in Casa Grande and maximum change in peroxidase activity of peel was observed in the case of New Hall cultivar.

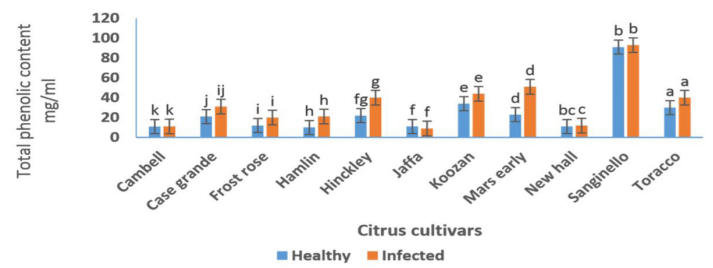

Figure 2. Effect of Citrus Tristeza virus infection on Total Phenolic content of different citrus fruits.

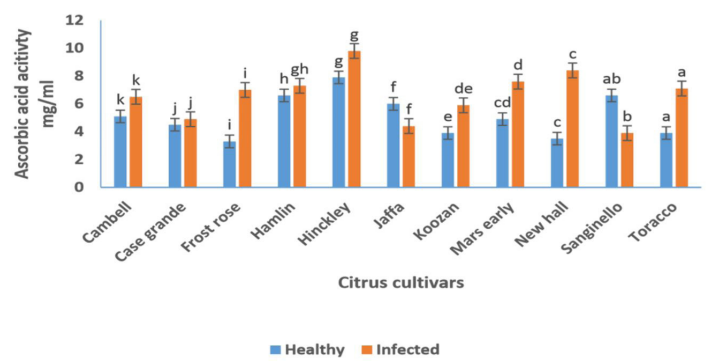

Figure 3. Effect of Citrus Tristeza virus infection on Ascorbic acid content of different citrus fruits.

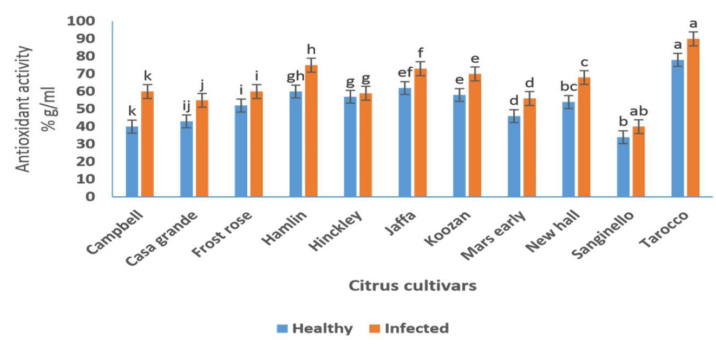

Figure 4. Effect of Citrus Tristeza virus infection on antioxidant activity of different citrus fruits.

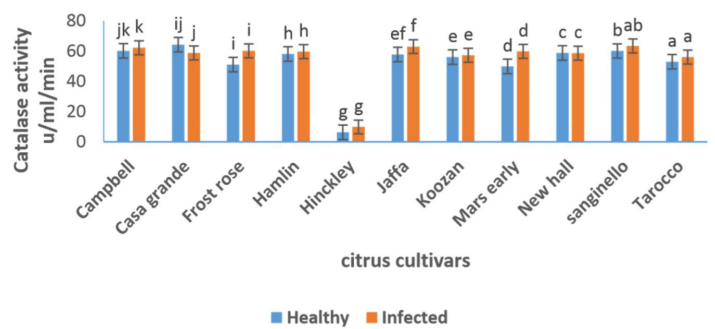

Figure 5. Effect of Citrus Tristeza virus infection on catalase activity of different citrus fruits.

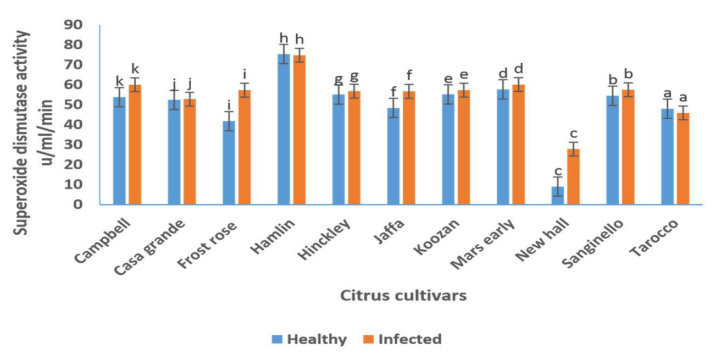

Figure 6. Effect of Citrus Tristeza virus infection on superoxide dismutase activity of different citrus fruits.

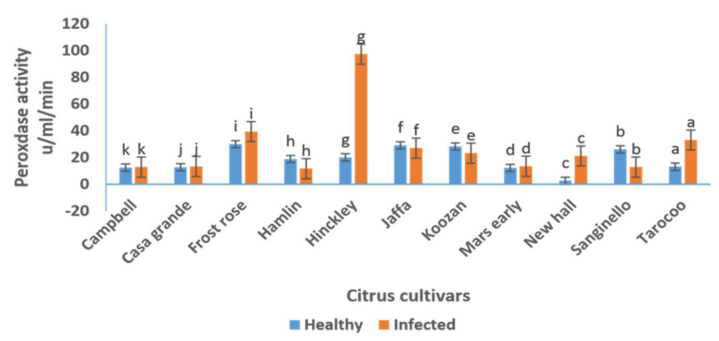

Figure 7. Effect of Citrus Tristeza virus infection on Peroxidase activity of different citrus fruits. 


\section{Discussion}

Flavonoids are secondary metabolites and their production increased in response to the entry of pathogens in citrus fruits (Suntornsuk et al., 2002). The phenolic, flavonoids and vitamin $\mathrm{C}$ act as antioxidant and during infection their amount increased and engulf the reactive oxygen species. Therefore, in infected cultivars the concentration of phenolic raised as compared to the healthy ones (Lee et al., 2003). However the deviation from this general trend was also recorded in some cultivars. e.g the general increase of flavonoid content for the majority of cultivars with the exception of Mars Early This may be due to the changes in biochemical pathways in response to disease. Like the other pathogens, during viral infection have also been reported to cause changes in antioxidants (Baker and Orlandi, 2005). Hence the results of the present work are in line with these earlier findings. These enzymes have been considered as important biomarkers in understanding the disease tolerance (Mittler et al., 2004). In earlier studies it has been reported that increase in SOD activity of citrus fruit can be correlated with resistance to CTV virus (Garcia-Limones et al., 2002). These findings are in accordance with the work of Ashry and Mohamed, (2011) who also reported higher peroxidase activities in peels as compared to fruits. It is evident from the results of the present work that the percentage of juice in the citrus fruits decreased after the disease infection. This symptom may be due to the fact that CTV virus sucks the sap from the phloem and in result the concentration of juice in citrus fruits decreased after the viral attack (Anagnostopoulou et al., 2006).

\section{Conclusion}

Citrus cultivars occupy a great importance in the food industry all around the globe. They contain plenty of bioactive compounds like flavonoids, phenolic, catalase, peroxidase and superoxide dismutase that act as an antioxidant in response to CTV. Hence the result of the present work indicated a general increase in both enzymatic as well as non-enzymatic antioxidants in response to CTV infection. So, these may be important biomarkers in response to CTV infection. However further investigations are required to find out the possible mechanism of disease tolerance of citrus plants. The antioxidant profiling in response to a viral infection may help in the discovery of new biomarkers that can be used as a monitoring tool during disease management.

\section{References}

ATTA, S., ZHOU, C.Y., YAN, Z., CAO, M.J. and WANG, X.F., 2012. Distribution and research advances of Citrus Tristeza virus. Journal of Integrative Agriculture, vol. 11, pp. 346-358.

ANAGNOSTOPOULOU, M.A., KEFALAS, P., PAPAGEORGIOU, V.P., ASSIMOPOULOU, A.N. and BOSKOU, D., 2006. Radical scavenging activity of various extracts and fractions of sweet orange peel (Citrus sinensis). Journal of Food Chemistry, vol. 94, no. 1, pp. 19-25.
ASHRY, N.A. and MOHAMED, H.I., 2011. Impact of secondary metabolites and related enzymes in flax resistance and or susceptibility to powdery mildew. Journal World of Agricultural Sciences, vol. 7, no. 1, pp. 78-85.

BAKER, C.J. and ORLANDI, E.W., 2005. Active oxygen in plant pathogenesis. Annual Review of Phytopathology, vol. 33, no. 1, pp. 299-321. PMid:18999963.

CAMBRA, M., GORRIS, M.T., MARROQUÍN, C., ROMÁN, M.P., OLMOS, A., MARTÍNEZ, M.C., MENDOZA, A.H., LÓPEZ, A. and NAVARRO, L., 2000. Incidence and epidemiology of Citrus Tristeza virus in the Valencian Community of Spain. Virus Research, vol. 71, no. 1-2, pp. 85-95. PMid:11137164.

DAS, K., TIWARI, R. and SHRIVASTAVA, D., 2010. Techniques for evaluation of medicinal plant products as antimicrobial agent: Current methods and future trends. Journal of Medicinal Plants Research, vol. 4, no. 2, pp. 104-111.

DJELOUAH, K. and D'ONGHIA, A., 2000. Occurrence and spread of citrus Tristeza in the Mediterranean area. Production and Exchange of Virus-free Plant Propagating Material in the Mediterranean Region, vol. 6, pp. 2004.

DÓRIA, M.S., SOUSA, A.O.D., BARBOSA, C.D.J., COSTA, M.G.C., GESTEIRA, A.D.S., SOUZA, R.M., FREITAS, A.C. and PIROVANI, C.P., 2015. Citrus Tristeza virus (CTV) causing proteomic and enzymatic changes in sweet orange variety "Westin". PLoS One, vol. 10, no. 7, pp. e0130950. PMid:26207751.

ELKAHOUI, S., HERNÁNDEZ, J.A., ABDELLY, C., GHRIR, R. and LIMAM, F., 2005. Effects of salt on lipid peroxidation and antioxidant enzyme activities of Catharanthus roseus suspension cells. Journal of Plant Sciences, vol. 168, no. 3, pp. 607-613.

FRANKE, A.A., CUSTER, L.J., ARAKAKI, C. and MURPHY, S.P., 2004. Vitamin C and flavonoid levels of fruits and vegetables consumed in Hawaii. Journal of Food Composition and Analysis, vol. 17 , no. 1 , pp. 1-35.

GARCÍA-LIMONES, C., HERVÁS, A., NAVAS-CORTÉS, J.A., JIMÉNEZ-DÍAZ, R.M. and TENA, M., 2002. Induction of an antioxidant enzyme system and other oxidative stress markers associated with compatible and incompatible interactions between chickpea (Cicer arietinum L.) and Fusarium oxysporum. Journal of Physiological and Molecular Plant Pathology, vol. 61, no. 6, pp. 325-337.

GHAFOOR, K., PARK, J. and CHOI, Y.H., 2010. Optimization of supercritical fluid extraction of bioactive compounds from grape (Vitis labrusca B.) peel by using response surface methodology. Journal of Innovative Food Science and Emerging Technologies, vol. 11 , no. 3 , pp. 485-490.

GORINSTEIN, S., CVIKROVA, M., MACHACKOVA, I., HARUENKIT, R., PARK, Y.-S., JUNG, S.-T., YAMAMOTO, K., AYALA, A.L.M., KATRICH, E. and TRAKHTENBERG, S., 2004. Characterization of antioxidant compounds in Jaffa sweeties and white grapefruits. Journal of Food Chemistry, vol. 84 , no. 4, pp. 503-510.

LATTANZIO, V., LATTANZIO, V.M. and CARDINALI, A., 2006. Role of phenolics in the resistance mechanisms of plants against fungal pathogens and insects. Phytochemistry: Advances in Research, vol. 661, pp. 23-67.

LEE, R., ROISTACHER, C., NIBLETT, C., LASTRA, R., ROCHA-PEÑA, M., GARNSEY, S., YOKOMI, R., GUMPF, D. and DODDS, J., 2003. Presence of Toxoptera citricidus in 
Central America: a threat to citrus in Florida and the United States. Journal of Citrus Industry, vol. 73, no. 6, pp. 13-14.

LIN, S., LAI, T.C., CHEN, L., KWOK, H.F., LAU, C.B.-S. and CHEUNG, P.C., 2014. Antioxidant and antiangiogenic properties of the phenolic extract from Pleurotus tuber-regium. Journal of Agricultural and Food Chemistry, vol. 62, no. 39, pp. 9488-9498. PMid:25185869.

MITTLER, R., VANDERAUWERA, S., GOLLERY, M. and VAN BREUSEGEM, F., 2004. Reactive oxygen gene network of plants. Journal of Trends in Plant Science, vol. 9, no. 10, pp. 490-498.

SUNTORNSUK, L., GRITSANAPUN, W., NILKAMHANK, S. and PAOCHOM, A., 2002. Quantitation of vitamin C content in herbal juice using direct titration. Journal of Pharmaceutical and Biomedical Analysis, vol. 28, no. 5, pp. 849-855. PMid:12039626.

ZHOU, Y., ZHOU, C. and WANG, X., 2011. Influence of the quantity and variability of Citrus Tristeza virus on transmissibility by single Toxoptera citricida. Journal of Plant Pathology, vol. 93, no. 1, pp. 97-103. . 